\title{
FAKTOR-FAKTOR YANG MEMPENGARUHI PENURUNAN POPULASI TERNAK KAMBING PERANAKAN ETAWA (Studi Kasus pada Kelompok Ternak Sukapala Kecamatan Kawalu Kota Tasikmalaya)
}

\author{
THE FACTORS THAT INFLUENCE THE DECLINE \\ IN ETAWA CROSSBREED GOATS POPULATION \\ (A Case Study in Sukapala Herd, Kawalu, Tasikmalaya City) \\ Ane Novianty*, Benidzar M. Andrie \\ Fakultas Pertanian Universitas Galuh \\ *E-mail corresponding: noviantyane29@gmail.com
}

\begin{abstract}
ABSTRAK
Peternak kambing Peranakan Etawa (PE) dihadapkan pada keadaan terbatasnya jumlah modal, faktor produksi dan pengetahuan dalam usaha untuk mencapai tujuannya. Kondisi tersebut menyebabkan turunnya populasi ternak kambing PE dari tahun ke tahun, meskipun produk yang dihasilkan memiliki peluang strategis di pasar. Tujuan penelitian ini untuk mengetahui faktorfaktor yang mempengaruhi penurunan populasi ternak kambing PE pada Kelompok Sukapala. Penelitian dilaksanakan pada kelompok ternak Sukapala Kecamatan Kawalu Kota Tasikmalaya yang berjumlah 9 orang dengan metode studi kasus. Faktor-faktor yang berpengaruh terhadap penurunan populasi ternak kambing PE berdasarkan uji regresi linear berganda yaitu modal $\left(\mathrm{X}_{1}\right)$, sistem pemeliharaan dan perawatan $\left(\mathrm{X}_{2}\right)$, kualitas bibit $\left(\mathrm{X}_{3}\right)$, dan kualitas pakan $\left(\mathrm{X}_{4}\right)$. Berdasarkan hasil pengujian secara simultan maupun parsial, keempat variabel independen tersebut berpengaruh secara nyata terhadap penurunan populasi ternak dan memiliki pengaruh yang negatif.
\end{abstract}

Kata kunci: kambing, peranakan etawa, penurunan populasi, regresi

\section{ABSTRACT}

Etawa breeders are faced with a situation with a limited amount of capital, production factor and knowledge in an effort to achieve their goal. This condition causes the decline of PE goat's population year by year even though the product produced has a strategic opportunity in the market. The purpose of this study is to determine the factors that influence the decline of PE goat's population in Sukapala herd. The study is carried out in Sukapala herd, Kawalu district, Tasikmalaya city which consists of 9 people by using a case study method. The factors that influence the decline of PE goat's population based on multiple linear regression test are capital $\left(X_{1}\right)$, treatment and maintenance system $\left(X_{2}\right)$, seed's quality $\left(X_{3}\right)$, and livestock breeds quality $\left(X_{4}\right)$. Based on the results of partially and simultaneously test, the four independent variables influence significantly in the decline of PE goat's population and have a negative effect.

Keywords: goat, etawa crossbreed, population decline, regression

\section{PENDAHULUAN}

Ternak kambing merupakan
komoditas peternakan yang erat
kaitannya dengan kehidupan masyarakat
di pedesaan. Biasanya kambing

dipelihara oleh peternak sebagai usaha sampingan, dan bahkan ada yang menjadikan sebagai usaha pokok mereka karena berpotensi meningkatkan perekonomian masyarakat kecil. Di 


\section{FAKTOR-FAKTOR YANG MEMPENGARUHI PENURUNAN \\ POPULASI TERNAK KAMBING PERANAKAN ETAWA \\ Ane Novianty, Benidzar M. Andrie}

banyak negara berkembang ternak kambing telah dijadikan sebagai komoditas strategis sebagai instrumen pengentasan kemiskinan (proverty alleviation) oleh kelembagaan internasional (Sodiq, 2010).

Peternakan kambing peranakan etawa (PE) saat ini berkembang pesat karena banyak hasil yang dapat diperoleh. Selain penghasil daging namun juga susu dan kulit (Rusdiana dkk, 2015). Jenis kambing PE mudah beradaptasi dengan kondisi iklim di Indonesia dan tidak terlalu memilih-milih pakan sehingga mudah dikembang biakkan di seluruh wilayah Indonesia (Sarim dan Ghupta, 2017).

Melihat banyaknya kelebihan dari beternak kambing PE, seharusnya dapat menjadi peluang strategis bagi peternak untuk memulai ternak kambing PE. Namun, pada kenyataannya banyak kelompok peternak kambing PE yang tidak konsisten dalam menjalankan usaha ternaknya. Peternak dihadapkan pada keadaan terbatasnya jumlah modal, faktor produksi dan pengetahuan dalam usaha untuk mencapai tujuannya. Kajian Rischkowsky (2017) menunjukkan bahwa tingkat penghasilan usaha ternak kambing menunjukkan peternak kurang memadai, meski harga pasar tinggi, dan kerap usaha peternak tiba-tiba berhenti.

Pernyataan di atas, salah satunya terjadi pada kelompok ternak Sukapala, Kecamatan Kawalu Kota Tasikmalaya. Jumlah populasi ternak pada tahun 2014 sebanyak 120 ekor dan mengalami penurunan setiap tahun nya hingga tahun 2020 hanya berjumlah 40 ekor dari 9 orang peternak.

Masalah yang biasanya terjadi pada usaha ternaknya adalah produktivitas susu yang sangat rendah. Rata-rata produktivitas susu yang dihasilkan adalah 0,2 liter/ekor/hari. Jumlah tersebut cukup jauh dari standar produksi susu kambing PE menurut Zurriyati, dkk (2011) berkisar antara 0,5-0,7 liter/ekor/hari. Produktivitas rendah dan pendapatan yang tidak meningkat signifikan dapat menjadi faktor penyebab peternak tidak termotivasi untuk mengembangkan usahanya sehingga populasi ternak nya dibiarkan menurun tanpa pengusahaan yang bernilai ekonomis.

Berdasarkan uraian di atas, maka penelitian ini dilaksanakan dengan tujuan untuk mengetahui faktor-faktor yang mempengaruhi penurunan populasi tenak kambing PE pada Kelompok Sukapala. 


\section{METODE PENELITIAN}

Jenis penelitian yang digunakan dalam penelitian ini adalah studi kasus pada kelompok ternak Sukapala di Kecamatan Kawalu Kota Tasikmalaya. Menurut Rahardjo dan Gudnanto (2011), studi kasus merupakan metode yang diterapkan untuk memahami individu lebih mendalam dengan dipraktekkan secara integratif dan komprehensif. Pengambilan data dilakukan pada seluruh anggota Kelompok Sukapala dengan sebanyak 9 orang.

Variabel penelitian yang diamati untuk mengetahui faktor-faktor yang mempengaruhi penurunan populasi ternak (Y) yaitu modal (X1), sistem perawatan dan pemeliharaan (X2), kualitas bibit (X3), dan kualitas pakan (X4). Untuk mengetahui faktor-faktor yang mempengaruhi penurunan populasi ternak kambing PE, maka dilakukan klasifikasi atau pengelompokan menurut Sugiyono (2000), dengan langkahlangkah sebagai berikut: (a) jawaban sangat setuju diberi skor 5; (b) jawaban setuju diberi skor 4; (c) jawaban netral diberi skor 3, (d) jawaban tidak setuju diberi skor 2; dan (e) jawaban sangat tidak setuju diberi skor 1, selanjutnya diuji dengan analisis regresi linear berganda.

\section{HASIL DAN PEMBAHASAN}

Uji asumsi klasik adalah persyaratan yang harus dipenuhi analisis regresi linier berganda yang berbasis ordinary least square (OLS). Pengujian asumsi klasik dalam penelitian ini dilakukan dengan 3 macam, yaitu uji normalitas, multikolinearitas, dan heteroskedastisitas.

\section{Uji Normalitas}

Uji normalitas berguna untuk membuktikan data dari sampel yang dimiliki berasal dari populasi berdistribusi normal atau tidak.

Tabel 1. Hasil Uji Normalitas Data

\begin{tabular}{lr}
\hline & \multicolumn{2}{c}{$\begin{array}{c}\text { Unstandardized } \\
\text { Residuals }\end{array}$} \\
\hline $\mathrm{N}$ & 9 \\
Kolmogorov-Smirnov & \\
$\mathrm{Z}$ & 0,579 \\
Asymp. Sig (2-tailed) & 0,891 \\
\hline
\end{tabular}

Sumber: Analisis Data Primer, 2020

Tabel 1 menunjukkan nilai signifikansi untuk uji normalitas sebesar 0,891, nilai ini lebih besar dari $\alpha 0,05$ sehingga data penelitian dari sampel sebanyak 9 orang berdistribusi normal dan dapat disimpulkan bahwa model regresi memenuhi syarat pengujian.

\section{Uji Multikolinearitas}

Pengujian multikolinearitas bertujuan untuk mengetahui apakah terdapat korelasi yang signifikan antar variabel independen dalam model regresi. 
Tabel 2. Hasil Uji Multikolinearitas

\begin{tabular}{|c|c|c|c|}
\hline \multirow{2}{*}{ Model } & \multicolumn{2}{|c|}{ Collinearity Statistics } & \multirow{2}{*}{ Kesimpulan } \\
\hline & Tolerance & VIF & \\
\hline \multicolumn{4}{|l|}{ Constant } \\
\hline Modal & 0,102 & 9,844 & Tidak ada Multikolinearitas \\
\hline Sistem Perawatan dan Pemeliharaan & 0,212 & 4,709 & Tidak ada Multikolinearitas \\
\hline Kualitas Bibit & 0,139 & 7,184 & Tidak ada Multikolinearitas \\
\hline Kualitas Pakan & 0,963 & 4,128 & Tidak ada Multikolinearitas \\
\hline
\end{tabular}

Sumber: Analisis Data Primer, 2020

Berdasarkan hasil uji multikolinearitas pada Tabel 2, diketahui bahwa seluruh variabel independen memiliki tolerance value lebih besar dari $\alpha$ 0,05 dan nilai VIF lebih kecil dari 10 . Hal ini menunjukkan bahwa tidak terdapat masalah multikolinearitas dan memenuhi prasyarat uji asumsi klasik.

\section{Uji Heteroskedastisitas}

Pengujian heteroskedastisitas bertujuan untuk mengetahui apakah dalam model regresi terdapat ketidaksamaan varians dari residual factor satu pengamatan ke pengamatan lain.

Tabel 3. Hasil Pengujian Heteroskedastisitas

\begin{tabular}{lll}
\hline \multicolumn{1}{c}{ Model } & Sig. & \multicolumn{1}{c}{ Kriteria } \\
\hline Modal (X1) & 0,427 & Homoskedastisitas \\
$\begin{array}{l}\text { Sistem } \\
\text { Perawatan dan }\end{array}$ & 0,316 & Homoskedastisitas \\
$\begin{array}{l}\text { Pemeliharaan } \\
\text { (X2) }\end{array}$ & & \\
$\begin{array}{l}\text { Kualitas Bibit } \\
\text { (X3) }\end{array}$ & 0,155 & Homoskedastisitas \\
$\begin{array}{l}\text { Kualitas Pakan } \\
(X 4)\end{array}$ & 0,224 & Homoskedastisitas \\
\hline
\end{tabular}

Sumber: Pengolahan data SPSS, 2020

Berdasarkan hasil uji heteroskedastisitas melalui uji Glesjer diketahui bahwa nilai signifikan korelasi seluruh variabel independen dengan nilai residual lebih besar dari $\alpha 0,05$. Dengan demikian model regresi yang digunakan tidak terdapat heteroskedastisitas atau data bersifat homoskedastisitas.

Berdasarkan seluruh hasil pengujian asumsi klasik model regresi, dapat dilihat bahwa data ber berdistribusi normal, tidak terjadi gejala multikolinearitas dan heteroskedastisitas, serta memenuhi aspek linearitas, sehingga model statistik yang digunakan layak untuk kondisi data pengamatan.

\section{Analisis Regresi Linear Berganda}

Dengan analisis regresi akan diketahui variabel independen yang benar-benar signifikan mempengaruhi variabel dependen dan dengan variabel yang signifikan tadi dapat digunakan untuk memprediksi nilai variabel dependen. 
Tabel 4. Pemodelan Regresi Berganda

\begin{tabular}{lr}
\hline Model & \multicolumn{1}{c}{$\begin{array}{l}\text { Unstandardized } \\
\text { Coefficients }\end{array}$} \\
\hline Constant & 3,021 \\
Modal (X1) & $-3,106$ \\
Sistem Perawatan dan & \\
Pemeliharaan (X2) & $-7,536$ \\
Kualitas Bibit (X3) & $-3,918$ \\
Kualitas Pakan (X4) & $-1,973$ \\
\hline Sumber: Pengolahan data SPSS, 2020 &
\end{tabular}

Tabel 4 menunjukkan model persamaan regresi yang diperoleh dengan koefisien konstanta dan koefisien variabel yang ada di kolom Unstandardized Coefficients. Berdasarkan Tabel 4 diperoleh model persamaan regresi yaitu:

$$
\begin{gathered}
\mathrm{Y}=3,022-3,106 \mathrm{X}_{1}-7,537 \mathrm{X}_{2}-3,918 \\
\mathrm{X}_{3}-1,973 \mathrm{X}_{4}
\end{gathered}
$$

Model regresi tersebut menunjukkan bahwa seluruh variabel independen yang digunakan bernilai negatif terhadap penurunan populasi ternak. Jadi, jika dilakukan penurunan faktor X sebanyak satu satuan, akan meningkatkan penurunan populasi ternak.

\section{Pengujian Koefisien Regresi Secara Serentak (uji F)}

Pengujian koefisien regresi secara serentak (uji F) digunakan untuk menguji pengaruh variabel independen yaitu Modal $\left(\mathrm{X}_{1}\right)$, Sistem Perawatan dan Pemeliharaan $\left(\mathrm{X}_{2}\right)$, Kualitas Bibit $\left(\mathrm{X}_{3}\right)$, dan Kualitas Pakan $\left(\mathrm{X}_{4}\right)$ berpengaruh secara simultan terhadap variabel dependen yaitu Penurunan Populasi Ternak (Y). $\mathrm{H}_{0}$ (hipotesis nol) dan $\mathrm{H}_{1}$ (hipotesis alternatif) dalam pengujian koefisien regresi secara serentak (uji F) dapat dilakukan dengan rumusan hipotesis sebagai berikut:

a. $H_{0}: \beta_{1}=\beta_{2}=\beta_{3}=\beta_{4}=0$

Berarti modal, sistem perawatan dan pemeliharaan, kualitas bibit, dan kualitas pakan tidak berpengaruh signifikan dan simultan terhadap penurunan populasi ternak.

b. $\mathrm{H}_{1}: \beta 1 \neq \beta 2 \neq \beta 3 \neq \beta 4 \neq 0$

Berarti modal, sistem perawatan dan pemeliharaan, kualitas bibit, dan kualitas pakan berpengaruh signifikan dan simultan terhadap penurunan populasi ternak.

Tabel 5. Hasil Pengujian Variabel Secara Simultan (Uji F)

\begin{tabular}{rlrcc} 
& Model & df & F & Sig \\
\hline 1 & Regression & 4 & 49,395 & 0,000 \\
& Residual & 6 & & \\
& Total & 9 & &
\end{tabular}

Sumber: Pengolahan data SPSS, 2020

Berdasarkan data hasil analisis pada tabel dapat dilihat nilai sig. yaitu sebesar $0,000<0,05$ maka dapat disimpulkan $\mathrm{H}_{0}$ ditolak. Berarti Modal, Sistem Perawatan dan Pemeliharaan, Kualitas Bibit, dan Kualitas Pakan berpengaruh signifikan dan simultan terhadap Penurunan 


\section{FAKTOR-FAKTOR YANG MEMPENGARUHI PENURUNAN \\ POPULASI TERNAK KAMBING PERANAKAN ETAWA \\ Ane Novianty, Benidzar M. Andrie}

Populasi ternak kambing peranakan etawa di Desa Sukapala Kota Tasikmalaya.

\section{Pengujian Koefisien Regresi Secara}

\section{Parsial (Uji t)}

Analisis ini digunakan untuk menentukan signifikansi masing-masing koefisien, pada persamaan regresi berganda atau untuk menguji pengaruh variabel independen yaitu Modal $\left(\mathrm{X}_{1}\right)$, Sistem Perawatan dan Pemeliharaan $\left(\mathrm{X}_{2}\right)$, Kualitas Bibit $\left(\mathrm{X}_{3}\right)$, dan Kualitas Pakan $\left(\mathrm{X}_{4}\right)$ berpengaruh secara parsial terhadap variabel dependen yaitu Penurunan Populasi Ternak.

Tabel 6. Hasil Pengujian Koefisien Regresi Secara Parsial (Uji t)

\begin{tabular}{|c|c|c|c|}
\hline \multirow[b]{2}{*}{ Model } & \multicolumn{2}{|c|}{$\begin{array}{c}\text { Unstandardized } \\
\text { Coefficients }\end{array}$} & \multirow[t]{2}{*}{ Sig } \\
\hline & B & $\begin{array}{l}\text { Std. } \\
\text { Error }\end{array}$ & \\
\hline 1 (Constant) & 4,971 & 1,645 & 0,003 \\
\hline Modal & $-0,241$ & 0,078 & 0,003 \\
\hline Sistem & & & \\
\hline $\begin{array}{l}\text { Perawatan dan } \\
\text { Pemeliharaan }\end{array}$ & $-0,618$ & 0,082 & 0,000 \\
\hline Kualitas Bibit & $-0,400$ & 0,102 & 0,000 \\
\hline Kualitas Pakan & $-0,199$ & 0,101 & 0,052 \\
\hline
\end{tabular}

Sumber: Pengolahan data SPSS, 2020

a. Nilai sig 0,003 $<\alpha \quad 0,05$ maka $\mathrm{H}_{0}$ ditolak. Berarti Modal berpengaruh signifikan dan positif terhadap Penurunan Populasi Ternak.

b. Nilai sig $0,000<\alpha \quad 0,05$ maka $\mathrm{H}_{0}$ ditolak. Berarti Sistem Perawatan dan
Pemeliharaan berpengaruh signifikan dan positif terhadap Penurunan Populasi Ternak.

c. Nilai sig $0,000<\alpha \quad 0,05$ maka $\mathrm{H}_{0}$ ditolak. Berarti Kualitas Bibit berpengaruh signifikan dan positif terhadap Penurunan Populasi Ternak.

d. Nilai sig 0,052 < $\alpha \quad 0,1$ maka $\mathrm{H}_{1}$ diterima. Berarti Kualitas Pakan berpengaruh signifikan terhadap Penurunan Populasi Ternak.pada tingkat kepercayaan $10 \%$.

Berdasarkan uji t, masing-masing variabel independen memiliki pengaruh terhadap variabel dependen. Sesuai dengan model regresi yang telah dijelaskan di atas, bahwa masing-masing variabel independen berpengaruh negatif terhadap penurunan populasi ternak. Jika faktor modal, sistem perawatan dan pemeliharaan, kualitas bibit serta kualitas pakan diturunkan atau lebih rendah dari standar, maka akan menjadi potensi penurunan populasi ternak kambing PE.

Jumlah modal akan menentukan skala usaha yang akan berpengaruh pada pola manajemen peternakan. Semakin besar modal yang dicurahkan, semakin besar kesempatan untuk menghasilkan pendapatan yang lebih besar, begitu pun sebaliknya. 
Jumlah kepemilikan kambing pada kelompok ternak Sukapala rata-rata kurang dari 10 ekor. Menurut Irmawati, dkk (2013), usaha ternak kambing dikatakan layak jika memelihara minimal 20 ekor kambing. Jika dilihat dari hasil penelitian yang dilakukan Prihatiningrum (2013), peternak kambing/domba dengan kepemilikan rata-rata 10 ekor, hanya memperoleh pendapatan Rp 676.873 per bulan.

Rata-rata pendapatan yang diterima oleh peternak tersebut tentu sulit untuk menambah populasi dengan cara pembelian kambing bakalan. Dengan kata lain, penambahan populasi hanya dapat dilakukan dengan siklus kelahiran anakan yang jumlah nya pun tidak tentu.

Usaha ternak kambing yang dijalankan oleh anggota kelompok ternak Sukapala merupakan usaha sampingan. Pemeliharaan ternak dilakukan secara ekstensif sehingga tidak ada motivasi dan upaya khusus dalam pengembangan usaha ternaknya. Pekerjaan utama para anggota peternak ini rata-rata sebagai buruh, dimana mereka hanya memiliki sisa waktu yang sedikit untuk melakukan pemeliharaan dan perawatan ternaknya. Padahal, pemeliharaan dan perawatan ternak berperan penting dalam peningkatan produksi dan pengembangan usaha ternak. Masrah, dkk (2016) menyatakan, efisiensi usaha ternak kambing pada sistem pemeliharaan secara intensif lebih efisien dibandingkan dengan sistem pemeliharaan secara semi intensif maupun ekstensif. Sementara sistem semi intensif lebih efisien dari sistem ekstensif.

Masalah selanjutnya yaitu terkait kualitas bibit. Bibit grade A dapat memproduksi susu rata-rata 1-1,5 liter/ekor/hari. Sedangkan para anggota kelompok ternak rata-rata hanya memiliki kambing grade $\mathrm{C}$ dan sedikit diantaranya merupakan grade $\mathrm{B}$ dengan produktivitas rata-rata $\quad 0,5-0,8$ liter/ekor/hari. Sejalan dengan pernyataan Rasminati (2013), bahwa bibit unggul menjadi suatu hal yang mutlak dalam rangka meningkatkan daya produksi ternak selanjutnya.

Selanjutnya terkait kualitas pakan, para peternak di kelompok ternak Sukapala biasanya hanya memberikan dedaunan yang ada di sekitar saja tanpa memperhatikan apakah pakan tersebut merangsang produksi susu atau tidak. Padahal saat ini telah banyak dikembangkan pakan konsentrat yang betul-betul memperhitungkan nutrisi yang sesuai dengan kebutuhan kambing PE. Rian, dkk (2015) menyatakan bahwa 
banyak faktor yang mempengaruhi produksi susu, tetapi jenis pakan dan kualitas pakan yang diberikan berpengaruh besar terhadap produksi susu yang dihasilkan.

\section{KESIMPULAN DAN SARAN}

Faktor-faktor yang mempengaruhi penurunan populasi ternak kambing PE yaitu modal, sistem pemeliharaan dan perawatan, kualitas bibit, dan kualitas pakan. Keempat variabel independen tersebut memiliki pengaruh negatif terhadap penurunan populasi ternak, sehingga untuk mempertahankan ataupun mengembangkan usaha, faktor-faktor tersebut harus benar-benar diperhatikan.

\section{UCAPAN TERIMA KASIH}

Terima kasih kepada DRPM Kemendikbud yang telah mendanai penelitian skim PDP ini.

\section{DAFTAR PUSTAKA}

Irmawati, D., A.M. Fuah,. Dan D.J. Setyono. (2013). Sistem Produksi dan Kelayakan Usaha Peternakan Kambing Peranakan Etawah (Studi Kasus di Kelompok Peternak Simpay Tampomas dan Tampomas Sejahtera, Jawa Barat. Jurnal Ilmu Produksi dan Teknologi Peternakan, 1(2): 104-109.

Masrah, Harapin, H., dan Saili, T. (2016). Kajian Produktivitas Ternak Kambing Pada Sistem
Pemeliharaan yang Berbeda di Kecamatan Andoolo Barat Kabupaten Konawe Selatan. Jitro, 3(1), 40-51.

Prihatiningrum, D.N. (2013). Penerapan Sistem Agribisnis Peternakan Kambing Jawa Randu dalam Kerangka Pengembangan Wilayah Kecamatan Karangpucung, Kabupaten Cilacap. Jurnal Wilayah dan Lingkungan, 1(2): 141-156.

Rasminati, S. (2013). Grade Kambing Peranakan Ettawa pada Kondisi Wilayah yang Berbeda. Sains Peternakan, 11(1): 43-48.

Rian, R., Yuni, S., Sigit, B., dan Ismaya. (2015). Produksi dan Komposisi Susu Kambing Peranakan Ettawa di Dataran Tinggi dan Dataran Rendah Daerah Istimewa Yogyakarta. Buletin Peternakan, 39(2): 180-188.

Rischkowsky, B. (2017). Update on the sheep and goat meat value chain transformation in Ethiopia. Paper pada workshop on developing intervention packages for small ruminant value chain target sites, Addis Ababa, 19-20 April 2017.

Rusdiana, S., L. Prahari dan Sumanto (2015). Kualitas dan Produktivitas Susu Kambing Perah Pesilangan di Indonesia. Jurnal Badan Litbang Pertanian, 34(2): 79-86.

Sarim dan Ghupta, R. (2017). Usaha Susu Kambing Peranakan Etawa (PE) Produksi Tharraya Farm di Desa Paya Kecamatan Sunggal Kabupaten Deli Serdang. Jurnal Pancabudi, 2(2): 1-8.

Sodiq, A. (2010). Pola Usaha Peternakan Kambing dan Kinerja Produktivitasnya di Wilayah EksKaresidenan Banyumas Jawa Tengah. Jurnal Agripet, 10 (2), 2010 .

Sugiyono. 2000. Statistika untuk Penelitian. Alfabeta, Bandung. 
Zurriyati, Y., R.R. Noor, dan R.R.A. Maheswari. (2011). Analisis Molekuler Genotipe Kappa Kasein (K-Kasein) dan Komposisi Susu Kambing Peranakan Etawah, Saanen dan Persilangannya. Jurnal Ilmu Ternak dan Veteriner, 16(1): 61-70.
Rahardjo. S dan Gudnanto. (2011). Pemahaman Individu Tekhnik Non Tes. Nora Media Enterprise, Kudus. 